\title{
In vitro effects of hop pellets and oak extracts in combination on ruminal fermentation parameters
}

\author{
Quynh Chau Dang Van ${ }^{(1,3)}$, Cécile Gardin ${ }^{(1)}$, Éric Mignolet ${ }^{(1)}$, Éric Froidmont ${ }^{(1,2)}$, \\ Michel Focant ${ }^{(1)}$, Yvan Larondelle ${ }^{(1)}$ \\ (1) Université catholique de Louvain. Institut des Sciences de la Vie. Croix du Sud, 2 box L7.05.08. BE-1348 Louvain-la- \\ Neuve (Belgium). \\ (2) Centre wallon de Recherches agronomiques. Département Production et Filières. Unité Nutrition animale et Durabilité. \\ Rue de Liroux, 8. BE-5030 Gembloux (Belgium). \\ (3) Haute École Charlemagne. Institut supérieur industriel agronomique. Rue Saint Victor, 3. BE-4500 Huy (Belgium). \\ E-mail: quynh.dangvan@hech.be
}

Received 27 October 2016, accepted 19 February 2018, available online 8 March 2018.

This article is distributed under the terms and conditions of the CC-BY License (http://creativecommons.org/licenses/by/4.0)

Description of the subject. Hop and oak extracts have been found to possess anti-methanogenic and protein-sparing effects in the rumen.

Objectives and method. An in vitro incubation with ruminal fluid was conducted to study the effects of increasing inclusions of hop pellets and oak extracts, alone or in combination, on ruminal fermentation parameters.

Results. The combination of hop pellets and oak extracts reduced total volatile fatty acid (VFA) production compared with the control (no additive), whereas these additives alone had no effect. The acetate/propionate ratio decreased with the combination of hop pellets and oak extracts, as compared to the control, whereas these additives alone had no effect. Hop pellets at the highest dose alone or in combination with oak extracts reduced the methane $\left(\mathrm{CH}_{4}\right)$ production, as compared to the control. The $\mathrm{CH}_{4}$ /VFA molar ratio was lower than the control for hop pellets at the highest dose combined with oak extracts, whereas the additives used alone had no effect. Ammonia $\mathrm{N}$ concentration was reduced by oak extracts treatments at the highest dose alone or in combination with hop pellets, as compared to the control.

Conclusions. Hop pellets and oak extracts altered in vitro rumen fermentation with some responses being non-linear when used in combination.

Keywords. Feed additives, rumen digestion, volatile fatty acids, in vitro, methane, ammonia.

Effets in vitro de granulés de houblon et d'extraits de chêne en combinaison sur les paramètres de fermentation ruminale Description du sujet. Les extraits de houblon et de chêne ont des effets anti-méthanogène et de protection des protéines contre la dégradation dans le rumen.

Objectifs et méthode. Une incubation in vitro avec du jus de rumen a été réalisée pour étudier les effets d'incorporations croissantes de granulés de houblon et d'extraits de chêne, seuls ou en combinaison, sur les paramètres de fermentation ruminale. Résultats. La combinaison de granulés de houblon et d'extraits de chêne a réduit la production totale d'acides gras volatils (AGV) par comparaison avec le contrôle (sans additif), alors que ces additifs seuls n'ont pas eu d'effet. Le rapport acétate/ propionate a diminué avec la combinaison de granulés de houblon et d'extraits de chêne, par comparaison avec le contrôle, alors que ces additifs seuls n'ont pas eu d'effet. Les granulés de houblon à la dose la plus élevée seuls ou associés aux extraits de chêne ont réduit la production de méthane $\left(\mathrm{CH}_{4}\right)$, par comparaison avec le contrôle. Le rapport molaire $\mathrm{CH}_{4} / \mathrm{AGV}$ a été plus faible pour les granulés de houblon à la dose la plus élevée associés avec les extraits de chêne, par comparaison avec le contrôle, alors que ces additifs seuls n'ont pas eu d'effet. La concentration en N ammoniacal a été réduite par les traitements avec les extraits de chêne à la dose la plus élevée seuls ou associés avec les granulés de houblon, par comparaison avec le contrôle.

Conclusions. Les granulés de houblon et les extraits de chêne modifient les fermentations in vitro avec quelques réponses non linéaires lorsqu'ils sont utilisés en combinaison.

Mots-clés. Additif aux aliments des animaux, digestion du rumen, acide gras volatil, in vitro, méthane, ammoniac. 


\section{INTRODUCTION}

Livestock are responsible for $44 \%$ of global anthropogenic methane $\left(\mathrm{CH}_{4}\right)$ emissions, mainly originating from ruminal fermentation (Gerber et al., 2013). Besides, $\mathrm{CH}_{4}$ outputs represent a significant energy loss to the ruminant, ranging from 2 to $15 \%$ of gross energy intake for Holstein cows (Holter \& Young, 1992). Ammonia $\left(\mathrm{NH}_{3}\right)$ outflows from the rumen, ranging from 20 to $35 \%$ of dietary $\mathrm{N}$, are converted to urea in the liver and excreted mainly in urine, a process that also represents a significant energy loss to the ruminant (Ulyatt et al., 1975). During manure storage, urea is quickly hydrolyzed to $\mathrm{NH}_{3}$ that can be later nitrified to nitrate $\left(\mathrm{NO}_{3}^{-}\right)$, which in turn could be converted to nitrous oxide $\left(\mathrm{N}_{2} \mathrm{O}\right)$ during denitrification (Eckard et al., 2010). Livestock are responsible for $53 \%$ of global anthropogenic $\mathrm{N}_{2} \mathrm{O}$ emissions (Gerber et al., 2013). Therefore, modifications of rumen microbial fermentation to decrease $\mathrm{CH}_{4}$ production and $\mathrm{NH}_{3}$ outflow, without altering ruminant production, are a useful strategy not only to reduce environmental pollution but also to improve production efficiency.

Hop (Humulus lupulus) has been used for centuries in the brewing industry to preserve beer from lactic acid bacteria contamination and provide bitterness and hop character to beer (Simpson, 1993). The agents in hop responsible for their antimicrobial properties are resinous bitter acids ( $\alpha$-acids or humulones and $\beta$-acids or lupulones) and their isomers, volatile oils (mainly terpenoids) and polyphenols located in the lupulin glands of the female hop cones (Teuber \& Schmalreck, 1973; Van Cleemput et al., 2009). Hop or $\alpha$ - and $\beta$-acids have been shown to inhibit most $\mathrm{Gram}^{+}$bacteria in a manner similar to monensin (Narvaez et al., 2013a). In an in vitro experiment, inclusion of hop at $476 \mathrm{mg} \cdot \mathrm{kg}^{-1}$ of dry matter (DM) in a barley-based diet increased the percentage of propionate in the total volatile fatty acids (VFA) and decreased the acetate/propionate (A/P) ratio (Wang et al., 2010). Inclusions of hop at levels between 400 and $800 \mathrm{mg} \cdot \mathrm{l}^{-1}$ of culture fluid in in vitro incubations of a barley-based diet reduced $\mathrm{CH}_{4}$ production and the A/P ratio (Narvaez et al., 2011; Narvaez et al., 2013b). Therefore, hop appears as a promising natural feed additive for decreasing ruminal $\mathrm{CH}_{4}$ production with minimum detrimental effects on the efficiency of ruminal fermentation.

The heartwood of the pedunculate oak (Quercus robur) is known to accumulate high amounts (10\% of DM) of ellagitannins (hydrolysable tannins), mainly hexahydroxydiphenoyl esters (mainly castalagin and vescalagin), which are responsible for the high durability of oak wood (Scalbert et al., 1988; Scalbert et al., 1990; García-Estévez et al., 2010). Some tannins (condensed and hydrolysable) added to ruminant diets have been shown to reduce ruminal $\mathrm{CH}_{4}$ and $\mathrm{NH}_{3}$ productions (by reducing ruminal protein degradation) without adversely affecting the efficiency of ruminal fermentation (Bhatta et al., 2009; Patra \& Saxena, 2011; Jayanegara et al., 2012). In an in vitro experiment, supplying chestnut (Castanea sativa) wood extract rich in hydrolysable tannins at $12 \mathrm{~g} \cdot \mathrm{kg}^{-1}$ of DM to a basal diet significantly reduced rumen $\mathrm{NH}_{3}$ (Sliwinski et al., 2002). Supplying chestnut and valonea (Quercus aegilops) extracts rich in hydrolysable tannins at 50 to $200 \mathrm{~g} \cdot \mathrm{kg}^{-1}$ of $\mathrm{DM}$ to a grass silage in vitro incubation reduced ruminal $\mathrm{CH}_{4}$ and $\mathrm{NH}_{3}$ productions with minimum detrimental effects on the total VFA concentration (Hassanat \& Benchaar, 2013; Wischer et al.,2013). Therefore, despite the scarcity of published data on the effects of oak on ruminal fermentation, oak extracts rich in hydrolysable tannins also appear as a promising natural feed additive for decreasing ruminal $\mathrm{CH}_{4}$ production and $\mathrm{NH}_{3}$ outflow without adversely affecting the efficiency of ruminal fermentation.

There is no information as to whether the effects on ruminal fermentation are linear or not when hop and wood tannins are supplied in combination. Therefore, the objective of the present study was to evaluate the effects of increasing inclusions of hop pellets and oak extracts alone or in combination on in vitro ruminal fermentation parameters.

\section{MATERIALS AND METHODS}

\subsection{Experimental treatments}

An in vitro incubation was conducted to study the effects of increasing inclusions of hop pellets and oak extracts, alone or in combination, on $\mathrm{pH}$, total and individual VFA, $\mathrm{CH}_{4}$ and $\mathrm{NH}_{3}-\mathrm{N}$ concentrations. The treatments were control (no additive), two doses of hop pellets (110 and $475 \mathrm{mg} \cdot \mathrm{l}^{-1}$ of culture fluid), two doses of oak extracts (101 and $309 \mathrm{mg} \cdot \mathrm{l}^{-1}$ of culture fluid), four combinations of hop pellets and oak extracts (110 and 101, 110 and 309, 475 and 101, 475 and $309 \mathrm{mg} \cdot \mathrm{l}^{-1}$ of culture fluid, respectively). The concentrations of hop pellets (110 and $\left.475 \mathrm{mg} \cdot 1^{-1}\right)$ correspond to inclusions of hop pellets of 11 and $45 \mathrm{~g}$. $\mathrm{kg}^{-1}$ of diet DM, whereas those of oak extracts (101 and $309 \mathrm{mg} \cdot \mathrm{l}^{-1}$ ) correspond to inclusions of oak extracts of 10 and $30 \mathrm{~g} \cdot \mathrm{kg}^{-1}$ of diet DM, respectively. The culture fluid was supplied with grass silage and white lupin seeds (Lupinus albus) in a 70/30 ratio (DM basis) as substrates. Lupin seeds partly substituted grass silage as substrates to provide degradable proteins in excess for rumen microorganisms. Hop pellets and oak extracts were added on top to the $250 \mathrm{mg}$ basal diet (175 mg grass silage $+75 \mathrm{mg}$ lupin seeds).

Hop (Humulus lupulus variety Zeus) was supplied in the form of pellets (Yakima Chief, 
Inc., Sunnyside, WA, USA). Hop pellets are dried, ground and pelleted raw hop cones. According to the statements of the manufacturer, hop pellets contained $14.2 \% \alpha$-acids (w/w) and $5.0 \% \beta$-acids (w/w). Oak extract was supplied in the form of a dark brown granulated powder extracted from the heartwood of the pedunculate oak (Quercus robur) (Oxylent S.A., Ghislenghien, Belgium). According to the statements of the manufacturer, the oak extract contained $61.37 \%$ of total polyphenols. Grass silage was lyophilized. Hop pellets, grass silage and lupin seeds were ground to pass through a $1-\mathrm{mm}$ mesh. All ingredients were stored at $-20{ }^{\circ} \mathrm{C}$ in vacuum-sealed containers until use. The chemical composition of the experimental treatments is shown in Table 1.

\subsection{In vitro incubation with ruminal fluid}

Cows used in this study were cared for in accordance with the recommendations on care and use of laboratory animals of the Université catholique de Louvain. Ruminal fluid was collected from three rumencannulated (Bar Diamond Inc., Parma, ID, USA) dry Holstein cows receiving grass silage ad libitum for three weeks. Cows were fed twice daily and had free access to water and mineral blocks. Ruminal fluid from each cow was collected before the morning meal, strained through two metal sieves (1 and 0.4-mm mesh) and finally brought to the laboratory under anaerobic conditions at $39^{\circ} \mathrm{C}$. Ruminal fluid from each cow was then mixed in a $1 / 4$ ratio $(\mathrm{v} / \mathrm{v})$ with bicarbonate buffer prepared as described by Goering \& Van Soest (1970), pre-warmed at $39^{\circ} \mathrm{C}$ and saturated with $\mathrm{CO}_{2}$. The culture fluid (mixture of ruminal fluid and buffer) was then gassed with $\mathrm{CO}_{2}$ to maintain anaerobic conditions. The incubation was conducted in $120 \mathrm{ml}$ glass gas-tight flasks containing $25 \mathrm{ml}$ of culture fluid with $250 \mathrm{mg}$ of substrates including or not (control) hop pellets and oak extracts (one run per treatment). Once filled up, the flasks were gassed with $\mathrm{CO}_{2}$ before being closed with rubber stoppers and crimped with aluminum caps, and finally placed in a shaking water bath $\left(160 \mathrm{rpm}, 39^{\circ} \mathrm{C}\right)$ and incubated for $24 \mathrm{~h}$. The number of samples used is 30 ( 3 cows $* 9$ treatments for the $24 \mathrm{~h}$ time point + 3 flasks for the $0 \mathrm{~h}$ time point). For the $0 \mathrm{~h}$ time point, the flasks were directly placed into a dry ice/ethanol bath. After $24 \mathrm{~h}$, the headspace gas pressure in the flasks was measured and a sample was taken for $\mathrm{CH}_{4}$ analysis. Incubations were then stopped by placing the flasks into a dry ice/ethanol bath. The $\mathrm{pH}$ was measured in thawed incubation medium and samples were taken for VFA and $\mathrm{NH}_{3}-\mathrm{N}$ determinations. A flask per cow per time point containing only the culture fluid and no feed was included in each incubation. It indicated the production (VFA or $\mathrm{CH}_{4}$ ) originating from the fermentation of the residual feed in the culture fluid (blank value), and was subtracted from the production of test flasks to obtain the net production.

\subsection{Measurements and chemical analyses}

Feed samples were analyzed for DM by oven-drying at $105^{\circ} \mathrm{C}$ for $16 \mathrm{~h}$ (adapted from methods 967.03 and 930.15; AOAC, 1995), crude ash by ashing at $550{ }^{\circ} \mathrm{C}$ for $16 \mathrm{~h}$ (adapted from methods 923.03, 967.04 and 942.05; AOAC, 1995), CP by the Kjeldahl method ( $\mathrm{N} \times$ 6.25) (adapted from methods 981.10 and 991.2; AOAC, 1995), NDF and ADF (Van Soest et al., 1991). Neutral detergent fiber and ADF were determined sequentially and were expressed without residual ash. Neutral detergent fiber was analyzed with the addition of $\alpha$-amylase and without sodium sulfite.

The $\mathrm{pH}$ was measured with a $\mathrm{pH}$ meter (WTW, Weilheim, Germany).

For the measurement of the $\mathrm{CH}_{4}$ production, once the incubation was finished (after $24 \mathrm{~h}$ ), the gas accumulated in the headspace of the flasks was measured and sampled using a pressure transducer

Table 1. Dry matter (DM) and chemical composition (\% of DM) of the experimental treatments - Matière sèche (DM) et composition chimique (\% of DM) des traitements expérimentaux.

\begin{tabular}{llllllllll}
\hline Treatment & \multicolumn{7}{l}{ Dry matter of culture fluid $\left(\mathrm{mg} \cdot \mathrm{l}^{-1}\right)$} \\
\hline Hop pellets & $0^{*}$ & 110 & 475 & 0 & 0 & 110 & 110 & 475 & 475 \\
Oak extracts & $0^{*}$ & 0 & 0 & 101 & 309 & 101 & 309 & 101 & 309 \\
DM (\%) & 88.75 & 88.76 & 88.77 & 88.83 & 88.97 & 88.83 & 88.98 & 88.84 & 88.98 \\
\hline \multicolumn{7}{l}{ Chemical composition (\% of DM) } \\
\hline Organic matter & 92.05 & 92.03 & 91.97 & 92.11 & 92.23 & 92.09 & 92.21 & 92.03 & 92.15 \\
CP & 21.55 & 21.53 & 21.45 & 21.35 & 20.95 & 21.33 & 20.94 & 21.26 & 20.89 \\
NDF & 48.21 & 48.01 & 47.34 & 47.74 & 46.79 & 47.54 & 46.61 & 46.90 & 46.01 \\
ADF & 31.63 & 31.52 & 31.15 & 31.32 & 30.70 & 31.21 & 30.60 & 30.86 & 30.28 \\
\hline
\end{tabular}

*: Control - témoin. 
connected to a pressure meter (Sper Scientific, Scottsdale, AZ, USA) and a gas-tight syringe assembly. For the $24 \mathrm{~h}$ flasks, a measurement and sampling was taken at $6 \mathrm{~h}$, then the headspace pressure was set to ambient pressure, and the flasks were placed back into the water bath to continue the incubation till $24 \mathrm{~h}$. This intermediary step is necessary to avoid a buildup of gaseous components in the headspace, which would ultimately reduce the rate of fermentation of the substrate (Theodorou et al., 1994). Methane was determined by GC (Global Analyzer Solutions, Breda, The Netherlands) equipped with four columns (Restek, Bellefonte, PA, USA) and two thermal conductivity detectors. The first detector used $\mathrm{N}_{2}$ as carrier gas and allows to determine $\mathrm{H}_{2}$, while the second detector used $\mathrm{He}$ as carrier gas and allows to determine $\mathrm{CO}_{2}, \mathrm{O}_{2}, \mathrm{~N}_{2}$, $\mathrm{CH}_{4}$ and $\mathrm{CO}$.

For the measurement of the VFA production, $5 \mathrm{ml}$ of incubation medium was stabilized with $1 \mathrm{ml}$ $\mathrm{H}_{2} \mathrm{SO}_{4} 0.6 \mathrm{~mol} \cdot \mathrm{l}^{-1}$ and stored at $-20{ }^{\circ} \mathrm{C}$ until analysis. After thawing, VFA samples were centrifuged at $700 \mathrm{xg}$ for $10 \mathrm{~min}$ and $1.2 \mathrm{ml}$ of the supernatant was collected. Two hundred $\mu 1$ of isopropanol solution (internal standard) were added to each sample, which was centrifuged at $15,000 \times \mathrm{g}$ for $5 \mathrm{~min}$ and filtered through a $0.45 \mu \mathrm{m}$ Chromafil filter (Macherey-Nagel, Duren, Germany). Volatile fatty acids were identified and quantified with an HPLC equipped with a solvent vacuum degasser (SpectraSYSTEM SCM1000), an isocratic pump (SpectraSYSTEM P1000XR), an auto sampler (Injection volume $60 \mu 1$, SpectraSYSTEM AS3000) and a refractive index detector (Surveyor RI Plus Detector) (all Thermo Fisher Scientific, San José, CA, USA). The system was operated using an Alltech IOA-1000 organic acid column (300 mm length $\times 7.8 \mathrm{~mm}$ internal diameter, Grace, Deerfield, IL, USA) at $50{ }^{\circ} \mathrm{C}$ with $5 \mathrm{mmol} \cdot 1^{-1} \mathrm{H}_{2} \mathrm{SO}_{4}$ as eluent at a flow rate of $0.4 \mathrm{ml} \cdot \mathrm{min}^{-1}$.

For the measurement of the $\mathrm{NH}_{3}$ accumulation, $5 \mathrm{ml}$ of incubation medium were stabilized with $0.5 \mathrm{ml}$ $\mathrm{H}_{3} \mathrm{PO}_{4} 0.5 \%(\mathrm{v} / \mathrm{v})$ and stored at $-20{ }^{\circ} \mathrm{C}$ until analysis. The procedure for $\mathrm{NH}_{3}$ determination is based on the Berthelot reaction and was adapted from Weatherburn (1967) using a spectrophotometer (SpectraMax 190, Molecular Devices, Berkshire, UK) equipped with a 630-nm filter.

\subsection{Calculations}

The amount of total gas produced in the flask was calculated applying the ideal gas law: $n=P V / R T$, where $\mathrm{n}$ is the amount of total gas in the flask (in mmol), $\mathrm{P}$ is the headspace pressure (in bar), $\mathrm{V}$ is the volume of gas in the flask $(95 \mathrm{ml}), \mathrm{R}$ is the gas constant $(0.083 \mathrm{bar}$ $\mathrm{ml} \cdot \mathrm{K}^{-1} \cdot \mathrm{mmol}^{-1}$ ) and $\mathrm{T}$ is the absolute temperature $(273+39 \mathrm{~K})$. The amount of $\mathrm{CH}_{4}$ produced in the flask (in mmol) was obtained by multiplying the amount of total gas in the flask (mmol) with the proportion of $\mathrm{CH}_{4}$ in the gas sample (molar \% of total gases). For the 24-h flasks, the total amount of $\mathrm{CH}_{4}$ in the flask is the sum of the amount of $\mathrm{CH}_{4}$ produced at $6 \mathrm{~h}$ (intermediary measurement) and that at $24 \mathrm{~h}$.

\subsection{Statistical analysis}

All data are reported as least-squares means \pm SEM and were analyzed using the MIXED procedure of SAS (version 9.3, SAS Institute Inc., Cary, NC, USA). The statistical model included cow, treatment and random error. Fixed effects included treatment. Cow was the random effect. When a significant treatment effect was observed, the TUKEY option was used to compare means. Overall differences between treatment means were considered to be significant when $p<0.05$.

\section{RESULTS}

The ruminal fluid (mean of three cows \pm s.d.) before incubation had a $\mathrm{pH}$ of $7.1 \pm 0.07$, and a total VFA concentration of $98.7 \pm 4.75 \mathrm{mmol} \cdot \mathrm{l}^{-1}$, with acetate, propionate, butyrate, iso-butyrate, valerate and isovalerate representing $68.80 \pm 1.881,15.56 \pm 0.572$, $11.05 \pm 0.931,0.18 \pm 0.017,2.21 \pm 0.849$ and 2.20 $\pm 0.667 \%$ of total VFA, respectively. The effects of increasing inclusions of hop pellets and oak extracts, alone or in combination, on $\mathrm{pH}$, VFA production and their molar percentages, $\mathrm{CH}_{4}$ production and $\mathrm{NH}_{3}-\mathrm{N}$ concentration after $24 \mathrm{~h}$ of incubation are summarized in Table 2.

Hop pellets at the highest dose $\left(475 \mathrm{mg} \cdot \mathrm{l}^{-1}\right)$ alone or in combination with oak extracts and the combination of hop pellets and oak extracts at $110 / 309 \mathrm{mg} \cdot \mathrm{l}^{-1}$ reduced total VFA production compared with the control, whereas hop pellets at $110 \mathrm{mg} \cdot \mathrm{l}^{-1}$ or oak extracts at $309 \mathrm{mg} \cdot \mathrm{l}^{-1}$ alone did not differ from the control. The reduction in total VFA production did not influence the $\mathrm{pH}$, due to the presence of the buffer in the culture fluid. Therefore, the $\mathrm{pH}$ remained within physiological values throughout the incubation. The acetate proportion decreased with the combination of hop pellets and oak extracts at the highest doses (475/309 $\left.\mathrm{mg} \cdot \mathrm{l}^{-1}\right)$, as compared to the control, while the propionate proportion increased. This caused a decline in the $\mathrm{A} / \mathrm{P}$ ratio. Hop pellets $\left(475 \mathrm{mg} \cdot \mathrm{l}^{-1}\right)$ or oak extracts (309 mg.1 $\mathrm{l}^{-1}$ ) used alone had no effect on acetate and propionate proportions. The butyrate proportion also increased with the combination of hop pellets and oak extracts at the highest doses $\left(475 / 309 \mathrm{mg} \cdot \mathrm{l}^{-1}\right)$, whereas the additives used alone at the same dose had no effect on this parameter. Valerate and branched-chain volatile fatty acids (BCVFA) were not affected by 


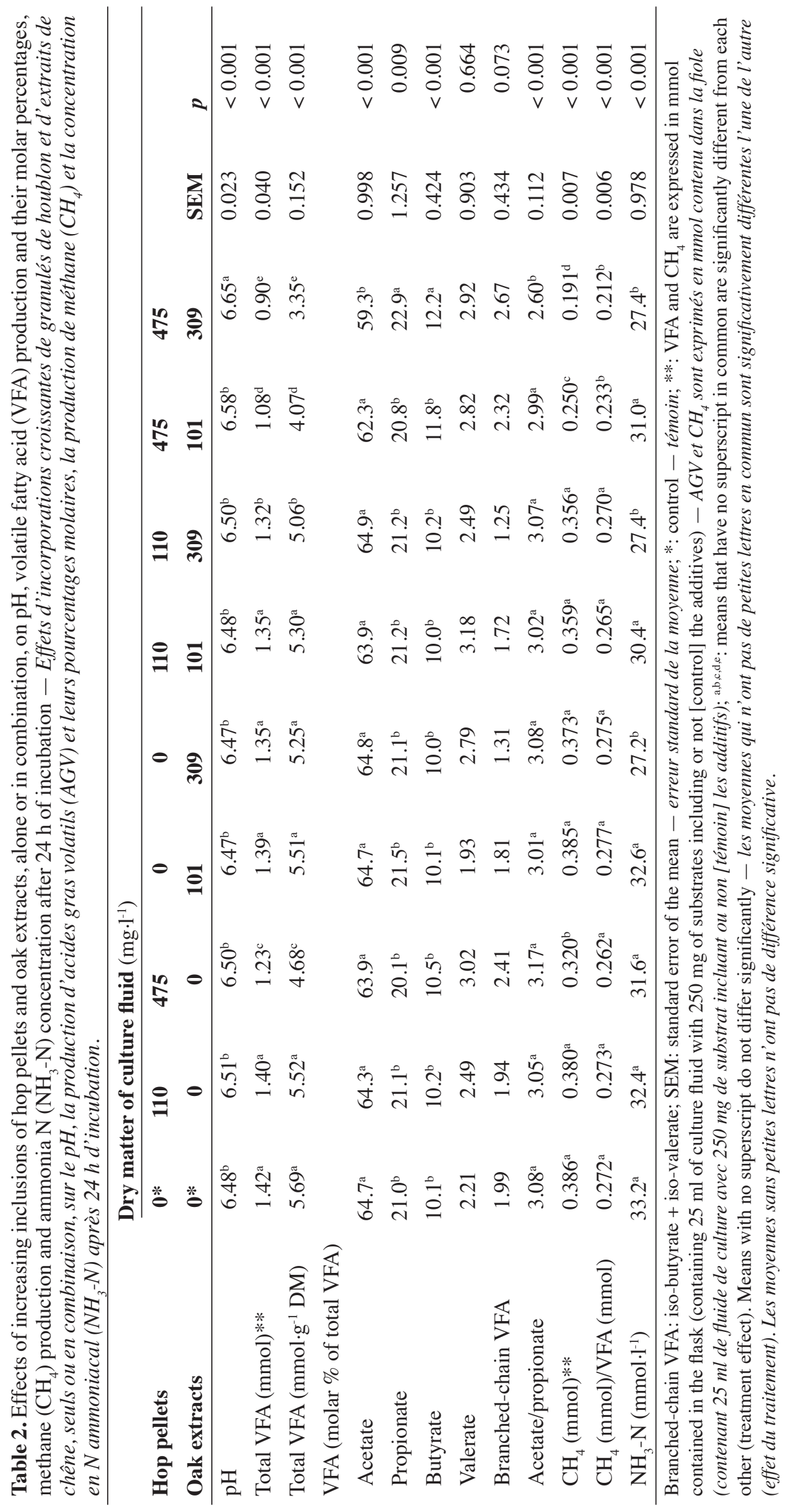


the treatments. Hop pellets at the highest dose alone or in combination with oak extracts reduced the $\mathrm{CH}_{4}$ production, as compared to the control. The $\mathrm{CH}_{4} /$ VFA molar ratio was lower than the control for hop pellets at the highest dose combined with oak extracts, whereas the additives used alone had no effect on this ratio. Ammonia $\mathrm{N}$ concentration was reduced by oak extracts treatments at the highest dose (309 $\left.\mathrm{mg} \cdot \mathrm{l}^{-1}\right)$ alone or in combination with hop pellets, as compared to the control.

\section{DISCUSSION}

The objective of the present study was to determine the potential of a preparation of hop pellets and oak extracts alone or in combination to reduce in vitro ruminal $\mathrm{CH}_{4}$ production and $\mathrm{NH}_{3}-\mathrm{N}$ concentration without adversely affecting total VFA production.

We hypothesized that efficient concentrations of additives could be lowered when they are used in combination, as compared to treatments with each additive alone, and that, due to differences in their modes of action, their combinations may be complementary in environmental terms, namely in the reduction of in vitro ruminal $\mathrm{CH}_{4}$ production on the one hand and $\mathrm{NH}_{3}-\mathrm{N}$ concentration on the other hand.

The treatment with hop pellets alone at $475 \mathrm{mg} \cdot \mathrm{l}^{-1}$ affected the fermentation process, as reflected by lower total VFA and $\mathrm{CH}_{4}$ productions. The effects on these ruminal fermentation parameters were even more pronounced when hop pellets at $475 \mathrm{mg} \cdot l^{-1}$ were combined with increasing doses of oak extracts (101 and $\left.309 \mathrm{mg} \cdot \mathrm{l}^{-1}\right)$. Indeed, hop pellets at $475 \mathrm{mg} \cdot \mathrm{l}^{-1}$ but not oak extracts at 101 or $309 \mathrm{mg} \cdot \mathrm{l}^{-1}$ depressed ruminal fermentation (relative change of $-14,-2,-5 \%$ for total VFA, respectively) and subsequent $\mathrm{CH}_{4}$ production (relative change of $-17,0,-4 \%$, respectively) but the effects were non-linear (non-additive or associative) when they were in combination (relative change of -24 or $-36 \%$ for total VFA and -35 or $-50 \%$ for $\mathrm{CH}_{4}$ production, respectively). In addition, the combination of hop pellets and oak extracts at 110/309 mg $\cdot 1^{-1}$ reduced total VFA production, as compared to the control, whereas these additives alone had no impact. The reduction in substrate degradation could be attributed to both additives. On the one hand, the reduction in substrate degradation attributed to hop pellets could be a result of the inhibition of $\mathrm{Gram}^{+}$cellulolytic bacteria (Flythe \& Aiken, 2010; Narvaez et al., 2013a; Lavrencic et al., 2015). In the in vitro study of Lavrencic et al. (2015), an inclusion of $1,200 \mathrm{mg} \cdot 1^{-1}$ of hop cones alone in the total mixed dairy cow ration decreased the total VFA production. On the other hand, the reduction in total VFA production attributed to oak extracts could be related to the formation of tannin- carbohydrate complexes that are less degradable or to direct inhibition of cellulolytic microorganisms or to combination of both effects (McSweeny et al., 2001; Hassanat \& Benchaar, 2013; Wischer et al., 2013). Inclusions of myrabolam or chestnut extracts containing hydrolysable tannins at $6,667 \mathrm{mg} \cdot \mathrm{l}^{-1}$ (Bhatta et al., 2009) or chestnut or valonea hydrolysable tannins at 50 to $200 \mathrm{~g} \cdot \mathrm{kg}^{-1}$ of DM (Hassanat \& Benchaar, 2013) or at $90 \mathrm{~g} \cdot \mathrm{kg}^{-1}$ of DM (Wischer et al., 2013) decreased the total VFA production in vitro. Interestingly, Bhatta et al. (2009) suggest that reduced $\mathrm{CH}_{4}$ production with hydrolysable tannins was primarily due to their antimethanogenic activity, and not solely because of reduced $\mathrm{OM}$ fermentation. Indeed, hydrolysable tannins suppressed methanogenesis, either by directly reducing the archaeal population, or indirectly by reducing the protozoal population, thereby reducing archaea symbiotically associated with the protozoa (Finlay et al., 1994; Bhatta et al., 2009; Patra \& Saxena, 2011).

A reduced $\mathrm{CH}_{4} / \mathrm{VFA}$ ratio, as compared to the control, was observed with the combinations of hop pellets at $475 \mathrm{mg} \cdot \mathrm{l}^{-1}$ and increasing doses of oak extracts, whereas a reduced $\mathrm{A} / \mathrm{P}$ ratio was observed only with the combination of hop pellets and oak extracts at $475 / 309 \mathrm{mg} \cdot \mathrm{l}^{-1}$. These results suggest that the mechanisms responsible for altering ruminal fermentation differ among the additives tested and are complementary when they are used in combination. Narvaez et al. (2013b) and Lavrencic et al. (2015) also found a decrease in the $\mathrm{A} / \mathrm{P}$ ratio when hop alone, at levels of 800 and $1,200 \mathrm{mg} \cdot \mathrm{l}^{-1}$, was added to in vitro diets. These authors used different hop varieties and attributed the effects on in vitro ruminal fermentation to variations in the concentration and activity of their $\alpha$ - and $\beta$-acids. However, the effects due to the varieties used were limited. Similar results were obtained by Flythe \& Aiken (2010) and Wang et al. (2010). The reduced $\mathrm{A} / \mathrm{P}$ ratio, which is the result of a reduction in acetate production coupled with an increase in that of propionate, indicates a shift in microbial populations towards propionate-producing bacteria and can be attributed to an inhibition of the activity of most $\mathrm{Gram}^{+}$ but not that of $\mathrm{Gram}^{-}$bacteria, therefore reducing the supply in metabolic $\mathrm{H}_{2}$ for methanogens (Narvaez et al., 2013a). The ionophore-like activity of hop or their $\alpha$ - and $\beta$-acids as major bioactive compounds similar to that of monensin has already been reported (Simpson, 1993; Behr \& Vogel, 2009; Narvaez et al., 2013a). Indeed, the hydrophobic parts of hop bitter acids interact with bacterial cell membranes by dissipating the transmembrane $\mathrm{pH}$ gradient and thus reducing the proton motive force, leading to inhibition of energy production, active nutrient transport and starvation of bacterial cells (Teuber \& Schmalreck, 1973; Simpson, 1993). Low $\mathrm{pH}$ favors antibacterial 
activity whereas high pH reduces it (Simpson, 1993). Hop may thus exert a greater favorable effect (reduction in $\mathrm{CH}_{4}$ production and $\mathrm{A} / \mathrm{P}$ ratio) on diets high in starch as compared to those high in fibre (Narvaez et al., 2011). The fact that the antibacterial activity of hop is restricted to $\mathrm{Gram}^{+}$bacteria, whereas Grambacteria are generally resistant, is probably due to the presence of a phospholipid-containing outer membrane surrounding Gram $^{-}$bacteria (Teuber \& Schmalreck, 1973; Russell \& Strobel, 1989). The observed decrease in $\mathrm{CH}_{4}$ production by hop can also be related to a direct inhibition of methanogens and redirection of $\mathrm{H}_{2}$ from $\mathrm{CH}_{4}$ towards propionate production (Narvaez et al. 2013a). Indeed, Narvaez et al. (2013a; 2013b) observed a reduction in the $16 \mathrm{~S}$ rRNA copy numbers associated with methanogens when hops were used.

Treatments with oak extracts at $309 \mathrm{mg} \cdot \mathrm{l}^{-1}$ with or without hop pellets reduced to the same extent $\mathrm{NH}_{3}-\mathrm{N}$ concentrations, as compared to the control, suggesting that the protein-sparing effect observed in this study can only be attributed to oak extracts. Published data on the response of the $\mathrm{NH}_{3}-\mathrm{N}$ concentration to hop are scarce (Flythe, 2009; Narvaez et al., 2011; Lavrencic et al., 2014). Flythe (2009) reported that hop inhibited in vitro the growth and $\mathrm{NH}_{3}$ production of pure cultures of three species of hyper $\mathrm{NH}_{3}$-producing bacteria and that similar effects could be expected in the rumen, although these three species may not represent all rumen hyper $\mathrm{NH}_{3}$-producing bacteria. Lavrencic et al. (2014) reported that in vitro crude protein degradability of substrates decreased with increasing concentrations of hop and suggested in turn that the amount of rumen bypass protein may be increased by this treatment. Amino acid deamination is mostly attributed to $\mathrm{Gram}^{+}$bacteria with a very high specific activity of $\mathrm{NH}_{3}$ production (Russell et al., 1988; Bento et al., 2015). Therefore, the mechanism of inhibition of hyper $\mathrm{NH}_{3}$-producing bacteria may be similar to that of acetate-producing bacteria and could be attributed to the ionophore-like activity of hop. However, hop pellets used in our study did not allow any reduction in the $\mathrm{NH}_{3}-\mathrm{N}$ concentration. Treatments with oak extracts treatments at $309 \mathrm{mg} \cdot \mathrm{l}^{-1}$ (or $30 \mathrm{~g} \cdot \mathrm{kg}^{-1}$ of DM) reduced the $\mathrm{NH}_{3}-\mathrm{N}$ concentration, as compared to the control. Similar in vitro observations were reported with inclusions of myrabolam or chestnut extracts containing hydrolysable tannins at $6,667 \mathrm{mg} \cdot \mathrm{l}^{-1}$ (Bhatta et al., 2009) or chestnut or valonea hydrolysable tannins at 50 to $200 \mathrm{~g} \cdot \mathrm{kg}^{-1}$ of DM (Hassanat \& Benchaar, 2013) or at $90 \mathrm{~g} \cdot \mathrm{kg}^{-1}$ of DM (Wischer et al., 2013). It has been well established that dietary tannins (condensed or hydrolysable) may protect dietary proteins from microbial degradation by interacting with them, on the one hand, by forming hydrogen bonds between the phenolic hydroxyl groups of tannins and carboxyl groups of aliphatic and aromatic side chains of dietary proteins, and, on the other hand, through hydrophobic interactions. This protective effect would cause a lowering of the ruminal $\mathrm{NH}_{3}$ and BCVFA concentrations and increasing ruminal escape of dietary protein (Mueller-Harvey, 2006; Bhatta et al., 2009; Patra \& Saxena, 2011). Ammonia is a product of amino acid deamination while BCVFA are products of the breakdown of the carbon skeleton of some amino acids during fermentation (Jouany et al., 1995). These tannin-protein complexes are unstable at the acidic $\mathrm{pH}$ of the abomasum and the dietary proteins thus become available for gastric or pancreatic digestion (Jones \& Mangan, 1977; Reed, 1995; Patra \& Saxena, 2011). Tannins have higher affinity to proteins than to carbohydrates (Patra \& Saxena, 2011). This may explain the more pronounced effect of oak extracts on $\mathrm{NH}_{3}-\mathrm{N}$ concentration, as compared to their effect on total VFA production during in vitro fermentation. The reduction of protein degradation in the rumen may also occur due to inhibition of the growth and enzyme activities of proteolytic bacteria (McSweeney et al., 2001; Patra \& Saxena, 2011).

\section{CONCLUSIONS}

Hop pellets and oak extracts tested in this study altered rumen fermentation with some responses being nonlinear when used in combination. Due to differences in their modes of action, dietary strategies that use combinations of hop pellets and oak extracts may be complementary to decrease the rumen $\mathrm{CH}_{4}$ production and the $\mathrm{NH}_{3}$ outflow in ruminants. In order to confirm the results and to test non-linearity by comparing combinations with the averages of the two individual additives used as the expected value, a new in vitro experiment should be performed with more runs per treatment. Also, the composition of active ingredients may differ from one batch of the additive to another. Additional in vitro experiments should therefore be performed with different batches in order to be representative enough for the plant species. Moreover, in vivo studies are required to confirm the effects of the use of these combined additives on rumen fermentation, overall feed efficiency, potential side effects on feed intake, potential long-term ruminal adaptation and economic viability. In addition, further studies are needed on fractionated extracts from hop and oak samples to identify the specific components responsible for the anti-methanogenic and proteinsparing effects observed in this study.

\section{Acknowledgements}

This work was supported by the Direction générale opérationnelle de l'Agriculture, des Ressources naturelles 
et de l'Environnement of the Service public de Wallonie (Project D31-1266), Dumoulin S.A. (Seilles, Belgium), Oxylent S.A. (Ghislenghien, Belgium) and Yakima Chief, Inc. (Louvain-la-Neuve, Belgium). The authors gratefully acknowledge C. Bichara, G. Chaput, G. Collignon, L. Van De Steene, D. Deswysen, P. Hamiet, S. Meurée and C. Turu from the Université catholique de Louvain (Louvainla-Neuve, Belgium) for fruitful discussions and their skilled assistance in animal care, feeding, sampling and laboratory analyses.

\section{Bibliography}

AOAC, 1995. Official methods of analysis. $16^{\text {th }}$ ed. Arlington, VA, USA: Association of Official Analytical Chemists.

Behr J. \& Vogel R.F., 2009. Mechanisms of hop inhibition: hop ionophores. J. Agric. Food Chem., 57, 6074-6081.

Bento C.B., de Azevedo A.C., Detmann E. \& Mantovani H.C., 2015. Biochemical and genetic diversity of carbohydrate-fermenting and obligate amino acid-fermenting hyper-ammonia-producing bacteria from Nellore steers fed tropical forages and supplemented with casein. BMC Microbiol., 15, 28.

Bhatta R. et al., 2009. Difference in the nature of tannins in in vitro ruminal methane and volatile fatty acid production and on methanogenic archaea and protozoal populations. J. Dairy Sci., 92, 5512-5522.

Eckard R.J., Grainger C. \& de Klein C.A.M., 2010. Options for the abatement of methane and nitrous oxide from ruminant production: a review. Livest. Sci., 130, 47-56.

Finlay B.J. et al., 1994. Some rumen ciliates have endosymbiotic methanogens. FEMS Microbiol. Lett., 117, 157-161.

Flythe M.D., 2009. The antimicrobial effects of hops (Humulus lupulus L.) on ruminal hyper ammoniaproducing bacteria. Lett. Appl. Microbiol., 48, 712-717.

Flythe M.D. \& Aiken G.E., 2010. Effects of hops (Humulus lupulus L.) extract on volatile fatty acid production by rumen bacteria. J. Appl. Microbiol., 109, 1169-1176.

García-Estévez I., $\quad$ Escribano-Bailón M.T., RivasGonzalo J.C. \& Alcalde-Eon C., 2010. Development of a fractionation method for the detection and identification of oak ellagitannins in red wines. Anal. Chim. Acta, 660 , 171-176.

Gerber P.J. et al., 2013. Tackling climate change through livestock - A global assessment of emissions and mitigation opportunities. Roma: FAO.

Goering H.K. \& Van Soest P.J., 1970. Forage fiber analyses (apparatus, reagents, procedures, and some applications). Agriculture Handbook No. 379. Washington: US Department of Agriculture.

Hassanat F. \& Benchaar C., 2013. Assessment of the effect of condensed (acacia and quebracho) and hydrolysable (chestnut and valonea) tannins on rumen fermentation and methane production in vitro. J. Sci. Food Agric., 93, 332-339.
Holter J.B. \& Young A.J., 1992. Methane prediction in dry and lactating Holstein cows. J. Dairy Sci., 75, 21652175.

Jayanegara A., Leiber F. \& Kreuzer M., 2012. Meta-analysis of the relationship between dietary tannin level and methane formation in ruminants from in vivo and in vitro experiments. J. Anim. Physiol. Anim. Nutr., 96, 365375.

Jones W.T. \& Mangan J.L., 1977. Complexes of the condensed tannins of sainfoin (Onobrychis viciifolia scop.) with fraction 1 leaf protein and with submaxillary mucoprotein, and their reversal by polyethylene glycol and pH. J. Sci. Food Agric., 28, 126-136.

Jouany J.P., Broudiscou L., Prins R.A. \& KomisarczukBony S., 1995. Chapitre 9. Métabolisme et nutrition de la population microbienne du rumen. In : Jarrige R. et al., éds. Nutrition des ruminants domestiques. Ingestion et digestion. Paris : Inra Éditions, 349-381.

Lavrencic A., Levart A., Kosir I.J. \& Cerenak A., 2014. Influence of two hop (Humulus lupulus L.) varieties on in vitro dry matter and crude protein degradability and digestibility in ruminants. J. Sci. Food Agric., 94, 12481252.

Lavrencic A., Levart A., Kosir I.J. \& Cerenak A., 2015. In vitro gas production kinetics and short-chain fatty acid production from rumen incubation of diets supplemented with hop cones (Humulus lupulus L.). Animal, 9, 576581 .

McSweeney C.S., Palmer B., McNeill D.M. \& Krause D.O., 2001. Microbial interactions with tannins: nutritional consequences for ruminants. Anim. Feed Sci. Technol., 91, 83-93.

Mueller-Harvey I., 2006. Unravelling the conundrum of tannins in animal nutrition and health. J. Sci. Food Agric., 86, 2010-2037.

Narvaez N., Wang Y., Xu Z. \& McAllister T., 2011. Effects of hops on in vitro ruminal fermentation of diets varying in forage content. Livest. Sci., 138, 193-201.

Narvaez N., Wang Y. \& McAllister T., 2013a. Effects of extracts of Humulus lupulus (hops) and Yucca schidigera applied alone or in combination with monensin on rumen fermentation and microbial populations in vitro. J. Sci. Food Agric., 93, 2517-2522.

Narvaez N. et al., 2013b. Effects of hop varieties on ruminal fermentation and bacterial community in an artificial rumen (rusitec). J. Sci. Food Agric., 93, 45-52.

Patra A.K. \& Saxena J., 2011. Exploitation of dietary tannins to improve rumen metabolism and ruminant nutrition. J. Sci. Food Agric., 91, 24-37.

Reed J.D., 1995. Nutritional toxicology of tannins and related polyphenols in forage legumes. J. Anim. Sci., 73, 1516-1528.

Russell J.B., Strobel H.J. \& Chen G., 1988. Enrichment and isolation of a ruminal bacterium with a very high specific activity of ammonia production. Appl. Environ. Microbiol., 54, 872-877. 
Russell J.B. \& Strobel H.J., 1989. Effect of ionophores on ruminal fermentation. Appl.Environ.Microbiol., 55, 1-6.

Scalbert A., Monties B. \& Favre J.M., 1988. Polyphenols of Quercus robur: adult tree and in vitro grown calli and shoots. Phytochemistry, 27, 3484-3488.

Scalbert A. et al., 1990. Polyphenols of Quercus robur L.: II. Preparative isolation by low-pressure and high-pressure liquid chromatography of heartwood ellagitannins. J. Chromatogr. A, 502, 107-119.

Simpson W.J., 1993. Studies on the sensitivity of lactic acid bacteria to hop bitter acids. J. Inst. Brew., 99, 405-411.

Sliwinski B.J., Soliva C.R., Machmüller A. \& Kreuzer M., 2002. Efficacy of plant extracts rich in secondary constituents to modify rumen fermentation. Anim. Feed Sci.Technol., 101, 101-114.

Teuber M. \& Schmalreck A.F., 1973. Membrane leakage in Bacillus subtilis 168 induced by the hop constituents lupulone, humulone, isohumulone and humulinic acid. Arch. Mikrobiol., 94, 159-171.

Theodorou M.K. et al., 1994. A simple gas production method using a pressure transducer to determine the fermentation kinetics of ruminant feeds. Anim. Feed Sci. Technol., 48, 185-197.
Ulyatt M.J., MacRae J.C., Clarke R.T.J. \& Pearce P.D., 1975. Quantitative digestion of fresh herbage by sheep. IV. Protein synthesis in the stomach. J. Agric. Sci. (Camb.), 84, 453-458.

Van Cleemput M. et al., 2009. Hop (Humulus lupulus)derived bitter acids as multipotent bioactive compounds. J. Nat. Prod., 72, 1220-1230.

Van Soest P.J., Robertson J.B. \& Lewis B.A., 1991. Methods for dietary fiber, neural detergent fiber and non-starch polysaccharides in relation to animal nutrition. J. Dairy Sci., 74, 3583-3597.

Wang Y.et al., 2010. Effects of hops on ruminal fermentation, growth, carcass traits and shedding of Escherichia coli of feedlot cattle. Livest. Sci., 129, 135-140.

Weatherburn M.W., 1967. Phenol-hypochlorite reaction for determination of ammonia. Anal. Chem., 39, 971-974.

Wischer G. et al., 2013. Effects of different tannin-rich extracts and rapeseed tannin monomers on methane formation and microbial protein synthesis in vitro. Animal, 7, 1796-1805.

(39 ref.) 